\title{
Influence of hydrogen cations on kinetics and equilibria of heavy-metal sorption by algae-sorption of copper cations by the alga Palmaria palmata (Linnaeus) Weber \& Mohr (Rhodophyta)
}

\author{
Andrzej Kłos • Malgorzata Rajfur
}

Received: 26 June 2012 / Revised and accepted: 20 December 2012 /Published online: 6 January 2013

(C) The Author(s) 2013. This article is published with open access at Springerlink.com

\begin{abstract}
The influence of hydrogen cations on kinetics and equilibria of sorption of copper cations by the marine alga Palmaria palmata (Linnaeus) Weber \& Mohr was studied under static conditions. The competitive effect of the $\mathrm{H}^{+}$ cations is described, which influenced the uncertainty of evaluation of the alga sorption capacity. Under static conditions, the variation of the $\mathrm{Cu}^{2+} / \mathrm{H}^{+}$concentration ratio during sorption was found nonmonotonic. The Langmuir isotherm model was used to determine the sorption capacity of the alga, namely $12.4 \mathrm{mg} \mathrm{g}^{-1}$ of dry algae mass. A similar value was determined from the kinetic parameters of the ionic exchange which is considered a pseudo-second-order chemical reaction. The consistent results indicated that the mathematical models used correctly described the equilibria and kinetics of the ionic exchange between algae and solutions.
\end{abstract}

Keywords Algae $\cdot$ Ionic exchange $\cdot$ Sorption kinetics and equilibria $\cdot$ Copper $\cdot \mathrm{pH}$

\section{Introduction}

There have been many scientific reports in recent years on equilibria and kinetics of heavy-metal sorption in various kinds of biomass, including algae (Bhat et al. 2008; Feng and Aldrich 2004; Gupta et al. 2010; Gupta and Rostogi 2008a; b; Rajfur et al. 2010), lichens (Hauck and Huneck

\footnotetext{
A. Kłos $\cdot$ M. Rajfur $(\bowtie)$

Chair of Biotechnology and Molecular Biology,

Opole University, ul. kard. B. Kominka 6,

45-032 Opole, Poland

e-mail: mrajfur@o2.pl

A. Kłos

e-mail: aklos@uni.opole.pl
}

2007), mosses (Balarama Krishna et al. 2004) and microorganisms (Vásquez et al. 2007). The main aim of these studies was to evaluate the possibility of using the living organisms or their dead biomass in the remediation processes (Monteiro et al. 2009). In addition, these studies were intended to reveal the influence of the competitive sorption of macroelements on traces of pollutants, such as heavy metals, contained in the organisms used for the biomonitoring of environmental pollution (Kłos et al. 2005; 2007). Similar evaluation has been applied to natural and modified mineral sorbents (GencFuhrman et al. 2007; Wu and Zhou 2009) and to physicochemically modified biological materials (Wong et al. 2003). The authors generally agree that sorption of heavy metals in biomass is mostly an ionic-exchange process. The algal cell wall consists mainly of polysaccharides, lipids, proteins and alginic acids. In selected species of algae, it is enriched with compounds such as calcium carbonate, chitin ( $\mathrm{N}$-acetylglucosamine polymer), silica and alginates (alginic acid salts). It contains 3-5-nm-sized pores, which makes it permeable to small molecule substances, such as water, metal ions and gas substances. The function groups responsible for the addition of heavy metal cations include amino, acetyl, hydroxyl, sulfo, carbonyl and carboxyl groups (Davis et al. 2003).

Mathematical models used to describe this process at equilibrium include the Freundlich isotherm model (Bulgariu and Bulgariu 2012; Kumar et al. 2008; Zhang 2011), the Langmuir model (Bulgariu and Bulgariu 2012; Kumar et al. 2008; Lee and Chang 2011) and the Redlich-Peterson and the KobleCorrigan models (El-Sikaily et al. 2007). Kinetics of the process is usually described with the first-order reaction model (Lagergren model), the second-order reaction model and the Weber and Morris model (Apiratikul and Pavasant 2008; Pavasant et al. 2006; Qaiser et al. 2009).

An important part of the sorption studies is evaluation of the influence of solution acidity $(\mathrm{pH})$ on the process. Numerous 
reports indicate that the maximal sorption of metals takes place in solutions of $\mathrm{pH}$ ranging from 4 to 6 , depending on the metal sorbed and the sorbent used. In acidic solutions, the sorption of heavy metals can be decreased by the competitive sorption of hydrogen cations (Singh et al. 2008), while in alkaline solutions, by the formation of hydrocomplexes (Uluozlu et al. 2008) and insoluble metal compounds, mainly hydroxides (Tuzen et al. 2009), as well as by the changes of the ionic forms of the metals (Herrero et al. 2005). Laboratory studies of equilibria and kinetics of heavy-metal sorption in algae under static conditions are usually carried out at $\mathrm{pH}$ lower than the $\mathrm{pH}$ of water in which the algae live naturally. In such experiments, metal cations are sorbed along with hydrogen cationsa fact already recognised (Chen et al. 2008) but often disregarded in discussions. On the other hand, the influence of the initial $\mathrm{pH}$ of solutions on the kinetic (Vilar et al. 2005) and equilibrium (Pavasant et al. 2006) parameters of sorption processes has also been indicated. The influence of temperature on sorption also has been studied (Gupta and Rostogi 2008a; Sari and Tuzen 2008).

This study aims aimed to evaluate: (1) the influence of hydrogen cations on the equilibria and kinetics of sorption of copper cations in the marine alga Palmaria palmata (Linnaeus) Weber \& Mohr; (2) the influence thereof on the uncertainty of determination of the alga sorption capacity; and (3) the interdependent parameters describing the equilibria and kinetics of the process.

\section{Materials and methods}

The marine alga Palmaria palmata, purchased at BogutynMłyn from Radzyń Podlaski (Poland), was used for the research. The thalli of these algae are multicellular, flattened and forked, approximately $20-50 \mathrm{~cm}$ long, darkred (Graham et al. 2009). The species was selected for the research due to its availability and easy preparation. The purchased biomass was in dried form. In order to remove salts released as a result of the destruction of cell membranes (Rajfur et al. 2012), the algae were rinsed with demineralised water (conductivity $\mathrm{K}=0.5 \mu \mathrm{S} \mathrm{cm}{ }^{-1}$ ) and dried for $24 \mathrm{~h}$ at $50{ }^{\circ} \mathrm{C}$. The algae prepared in this way were stored in tightly closed polyethylene containers. The concentration of copper naturally accumulated in the alga equalled to 0.0033 $\pm 0.0008 \mathrm{mg} \mathrm{g}^{-1} \mathrm{~d}$.m. Copper was selected due to a good repeatability of the results with the AAS method.

Study of the sorption equilibria and kinetics

Directly before each experiment, alga samples were immersed in demineralised water for $30 \mathrm{~min}$ to remove mineral salts released through broken cell membranes (Rajfur et al. 2012). All experiments were carried out at room temperature. Each sample (1.0 g dry algae mass (DM)) was placed in a perforated container of $30 \mathrm{~mL}$ volume and immersed in $0.4000 \mathrm{~L} \mathrm{CuSO}_{4}$ solution. The solution was intensively mixed with a magnetic stirrer.

The frequently reported influence of $\mathrm{pH}$ on the sorption of heavy metals was confirmed by placing the prepared alga samples in $0.5 \mathrm{mmol} \mathrm{L}^{-1}$ solutions of copper sulphate of various acidities ranging from $\mathrm{pH} 3$ to $\mathrm{pH} 9$. The acidity of solutions was stabilised with $0.01 \mathrm{~mol} \mathrm{~L}^{-1}$ solutions of hydrochloric acid or sodium hydroxide. The sorption was carried out for $70 \mathrm{~min}$, until the equilibrium was reached. After sorption, alga samples were mineralised and analysed for copper content.

Kinetics of sorption was assessed in similar experiments carried out for 70 min until the equilibrium was reached. Samples of the solution were taken periodically and analysed for copper content using AAS. The solution volume decreased upon sampling for about $0.020 \mathrm{~L}$ (5\% of the initial volume). Changes of the solution $\mathrm{pH}$ were also recorded. The equilibrium parameters obtained were used to determine the Langmuir isotherm (Langmuir 1918).

\section{Analytical equipment and chemicals}

Heavy metals were determined with an atomic absorption spectrometer SOLAAR 969 UNICAM (Thermo Electron Corporation, USA). The spectrometer was calibrated against standards obtained from ANALYTIKA Ltd., Czech Republic. The largest concentration of the calibration solution, namely $5 \mathrm{mg} \mathrm{L}^{-1}$ copper, was assumed an upper limit of linear response of the apparatus. The $\mathrm{pH}$ of solutions in which alga samples were immersed was measured with a CP551 pH-meter from Elmetron Zabrze, Poland. The absolute error of readings was $\Delta \mathrm{pH}=0.02$. Alga samples were mineralised with a microwave mineraliser MARS-X from CEM. All chemicals used were purchased from MERCK.

\section{Quality control}

The detection and quantification limits for copper equalled 0.0045 and $0.041 \mathrm{mg} \mathrm{L}^{-1}$, respectively. The quality control of measurements was assured by test analyses of the BCR 414 plankton and BCR-482 lichen reference materials from the Institute for Reference Materials and Measurements in Belgium. The obtained results are summarised in Table 1 .

The results presented in Table 1 confirm the relevance of the choice of copper as the element applied for the research.

Statistical evaluation of the results

The uncertainty of measurement results was evaluated using: standard errors (SE) of the parameters of straight lines defined by Eqs. (1) and (2); coefficients of 
Table 1 Measured and certified values of $\mathrm{Cu}$ concentration in the BCR 414 plankton and BCR 482 lichen reference material

\begin{tabular}{|c|c|c|c|c|c|c|c|c|c|}
\hline \multicolumn{4}{|c|}{ BCR 414 plankton } & \multicolumn{6}{|c|}{ BCR 482 lichen } \\
\hline \multirow[t]{2}{*}{$\mathrm{Cv}$} & \multirow[t]{2}{*}{$\pm \mathrm{U}$} & \multicolumn{2}{|l|}{ AAS } & \multirow[t]{2}{*}{$\mathrm{D}$} & \multirow[t]{2}{*}{$\mathrm{Cv}$} & \multirow[t]{2}{*}{$\pm \mathrm{U}$} & \multicolumn{2}{|l|}{ AAS } & \multirow[t]{2}{*}{$\mathrm{D}$} \\
\hline & & Mean & $\pm \mathrm{SD}$ & & & & Mean & $\pm \mathrm{SD}$ & \\
\hline$\left(\mu \mathrm{g} \mathrm{g}^{-1}\right)$ & $\left(\mu \mathrm{g} \mathrm{g}^{-1}\right)$ & $\left(\mu g^{-1}\right)$ & $\left(\mu \mathrm{g}^{-1}\right)$ & $(\%)$ & $\left(\mu \mathrm{g} \mathrm{g}^{-1}\right)$ & $\left(\mu \mathrm{g} \mathrm{g}^{-1}\right)$ & $\left(\mu \mathrm{g} \mathrm{g}^{-1}\right)$ & $\left(\mu \mathrm{g} \mathrm{g}^{-1}\right)$ & $(\%)$ \\
\hline 29.5 & 1.3 & 27.8 & 1.9 & -5.8 & 7.03 & 0.19 & 6.54 & 0.18 & -7.0 \\
\hline
\end{tabular}

Cv Certified value, U Uncertainty; SD Standard deviation, D Deviation (the relative difference between measured and certified concentrations, in \%)

determination $\mathrm{R}^{2}$ for these straight lines; and direct comparison of $\mathrm{c}^{*} \mathrm{Kt}(\mathrm{a}, 1)$ values determined independently within the kinetic and equilibrium analyses. The statistical evaluation was done both in regard to copper cations and to the sum of $\mathrm{H}^{+}$and $\mathrm{Cu}^{2+}$ cations. For statistical computations, the $\mathrm{R}$ language ( $\mathrm{R}$ Development Core Team 2009) was used.

\section{Results}

For the purpose of detailed comparison of the equilibrium and kinetic parameters of sorption of divalent copper cations and monovalent hydrogen cations, the concentrations thereof were expressed as $\mathrm{c}^{*}=\mathrm{Z} \cdot \mathrm{c}$, where: $\mathrm{z}$ is the cation valency (dimensionless) and $\mathrm{c}$ is the concentration of cations in $\mathrm{mmol} \mathrm{L}^{-1}$ or $\mathrm{mmol} \mathrm{g}^{-1}$. The transformation made the comparison of gram equivalents of cations (former val unit) possible without violating the rules of the SI system (mol units). Table 2 shows the concentrations of copper cations $c^{*}$ determined in solutions (s) and in alga samples (a), before (0) and after (1) sorption, initial and final values of solution $\mathrm{pH}$ and the gram equivalent fractions of copper in the initial solutions $\mathrm{x}^{*} \mathrm{Cu(s,0)}=\mathrm{c}^{*} \mathrm{Cu}(\mathrm{s}, 0)\left(\mathrm{c}^{*} \mathrm{Cu}\right.$ $\left.(\mathrm{s}, 0)+\mathrm{c}^{*} \mathrm{H}(\mathrm{s}, 0)\right)^{-1}$. The initial concentrations of hydrogen and copper ions in alga samples were assumed null.

Preliminary evaluation of results showed that increasing of the initial gram equivalent fraction of copper in solutions of equal initial $\mathrm{pH}$ reduced the competitive sorption of hydrogen cations. Thus, the sum of sorbed hydrogen and copper cations should be used for determination of sorption capacity of algae under assumption that $\mathrm{c}^{*} \mathrm{Cu}(\mathrm{s}, 0) \rightarrow \infty$.

Competitive sorption of hydrogen ions

Plots in Fig. 1 show how the quotients of copper and hydrogen concentrations in algae and in solution changed in time during sorption (the measurement series 6, Table 2).

The variation of the concentration quotient of copper and hydrogen in solutions was clearly nonmonotonic. In the initial period of sorption, the quotient $\mathrm{c}^{*} \mathrm{Cu}(\mathrm{s}, \mathrm{t})\left(\mathrm{c}_{\mathrm{H}(\mathrm{s}, \mathrm{t})}\right)^{-1}$ in the solution increased and so did the quotient in algae, $\mathrm{c}^{*} \mathrm{Cu}(\mathrm{a}, \mathrm{t})\left(\mathrm{c}^{*} \mathrm{H}(\mathrm{a}, \mathrm{t})\right)^{-1}$. It was possible if the increase of copper concentration in algae exceeded that of hydrogen concentration: $\mathrm{dc}_{\mathrm{Cu}(\mathrm{a}, \mathrm{t})}(\mathrm{dt})^{-1}>\mathrm{dc}_{\mathrm{H}(\mathrm{a}, \mathrm{t})}(\mathrm{dt})^{-1}$; and if the decrease of copper concentration in solution relative to the initial concentration of copper in solution was smaller than the similar decrease of hydrogen concentration in solution: $-\mathrm{dc}_{\mathrm{Cu}(\mathrm{s}, \mathrm{t})}$ $\left(\mathrm{c}_{\mathrm{Cu}(\mathrm{s}, 0)} \mathrm{dt}\right)^{-1}<-\mathrm{dc}_{\mathrm{H}(\mathrm{s}, \mathrm{t})}\left(\mathrm{c}_{\mathrm{H}(\mathrm{s}, 0)} \mathrm{dt}\right)^{-1}$. After the maximum value of $\mathrm{c}^{*} \mathrm{Cu}(\mathrm{s}, \mathrm{t})\left(\mathrm{c}^{*} \mathrm{H}(\mathrm{s}, \mathrm{t})\right)^{-1}$ was reached (point $\mathrm{A}$ in Fig. 1), the conditions changed to: $\mathrm{dc}_{\mathrm{Cu}(\mathrm{a}, \mathrm{t})}(\mathrm{dt})^{-1}>\mathrm{dc}_{\mathrm{H}(\mathrm{a}, \mathrm{t})}$ $(\mathrm{dt})^{-1}$ and $-\mathrm{dc}_{\mathrm{Cu}(\mathrm{s}, \mathrm{t})}\left(\mathrm{c}_{\mathrm{Cu}(\mathrm{s}, 0)} \mathrm{dt}\right)^{-1}>-\mathrm{dc}_{\mathrm{H}(\mathrm{s}, \mathrm{t})}\left(\mathrm{c}_{\mathrm{H}(\mathrm{s}, 0)} \mathrm{dt}\right)^{-1}$. Thus, the sorption of copper ions in algae had two phases-the first one which lasted until the relative equilibrium of chemical potentials of $\mathrm{H}^{+}$and $\mathrm{Cu}^{2+}$ in
Table 2 Concentration of copper in dry mass of algae and in solutions, and the $\mathrm{pH}$ of solutions before and after sorption

\begin{tabular}{lllllll}
\hline $\begin{array}{l}\text { Measurement } \\
\text { series }\end{array}$ & $\begin{array}{l}\mathrm{c}_{\mathrm{Cu}(\mathrm{s}, 0)} \mathrm{mmol} \mathrm{L}^{-1} \\
\mathrm{mmo}\end{array}$ & $\begin{array}{l}\mathrm{c}_{\mathrm{Cu}(\mathrm{s}, 1)} \mathrm{mmol} \mathrm{L}^{-1} \\
1\end{array}$ & $\begin{array}{l}\mathrm{c}_{\mathrm{Cu}(\mathrm{a}, 1)} \\
\mathrm{mmol} \mathrm{g}^{-1}\end{array}$ & $\mathrm{pH}_{0}$ & $\mathrm{pH}_{1}$ & $\mathrm{x}_{\mathrm{Cu}(\mathrm{s}, 0)}$ \\
\hline 2 & 0.0346 & 0.0016 & 0.0132 & $4.73 \pm 0.05$ & 6.04 & 0.65 \\
3 & 0.0463 & 0.0025 & 0.0175 & & 5.96 & 0.71 \\
4 & 0.0724 & 0.0031 & 0.0277 & & 5.96 & 0.80 \\
5 & 0.0998 & 0.0047 & 0.0380 & & 5.73 & 0.84 \\
6 & 0.1309 & 0.0057 & 0.0501 & & 5.68 & 0.88 \\
7 & 0.1520 & 0.0076 & 0.0578 & & 5.60 & 0.89 \\
8 & 0.0803 & 0.0038 & 0.0306 & 4.0 & 5.36 & 0.45 \\
\hline
\end{tabular}




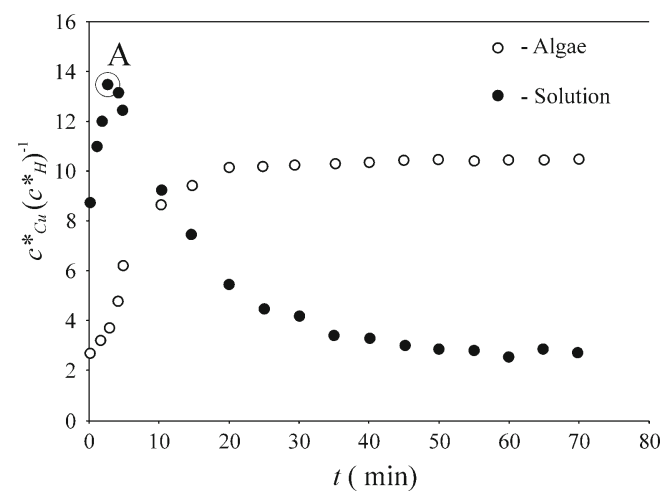

Fig. 1 Variation of the concentration quotients of copper and hydrogen in algae and in solution during sorption

solution was reached (point A), and the second one in which the sorption of both cations was mutually proportional and governed by thermodynamic conditions and cation concentrations. The time in which point $\mathrm{A}$ was reached increased when the initial $\mathrm{pH}$ of solutions was decreased.

To sum up, the $\mathrm{pH}$ of solutions influenced not only the equilibria of copper sorption, but also the kinetics of the process, especially in the initial phase.

Figure 2 shows the influence of the gram equivalent fraction of copper in the initial solution, $\mathrm{x}_{\mathrm{Cu}(\mathrm{s}, 0)}=\mathrm{c}^{*} \mathrm{Cu(s,0)}$ $\left(\mathrm{c}^{*} \mathrm{Cu}(\mathrm{s}, 0)+\mathrm{c}^{*} \mathrm{H}(\mathrm{s}, 0)\right)^{-1}$, on the magnitude of the concentration quotient at point $\mathrm{A}$.

The relation in Fig. 1 is explainable. If $\mathrm{x}^{*} \mathrm{Cu(s,0)}=0$, there are no copper cations in the solution, so $\mathrm{c}^{*} \mathrm{Cu}(\mathrm{s}, \mathrm{A})$ $\left(\mathrm{c}^{*} \mathrm{H}(\mathrm{s}, \mathrm{A})\right)^{-1}=0$. If $\mathrm{x}^{*} \mathrm{Cu}(\mathrm{s}, 0) \rightarrow 1$, then $\mathrm{c}^{*} \mathrm{Cu}(\mathrm{s}, 0) \quad\left(\mathrm{c}^{*} \mathrm{H}\right.$ $(\mathrm{s}, 0))^{-1} \rightarrow \infty$. However, the relation has an upper limit resulting from the dissociation of water and solubility of metal hydroxides. A metal hydroxide precipitates when the acidity of solution exceeds the value of $\mathrm{pH}=$ $z^{-1} \quad\left(14 \quad z-\log c_{M e}-p K_{s p}\right)$, where: $z$ is the valency of the metal cation; $\mathrm{c}_{\mathrm{Me}}$ is the concentration of metal cations in solution $\left(\mathrm{mol} \# \mathrm{~L}^{-1}\right)$; and $\mathrm{K}_{\mathrm{sp}}$ is the solubility product of metal hydroxide; $\mathrm{pK}_{\mathrm{sp}}=-\log \left(\mathrm{K}_{\mathrm{sp}}\right)$.

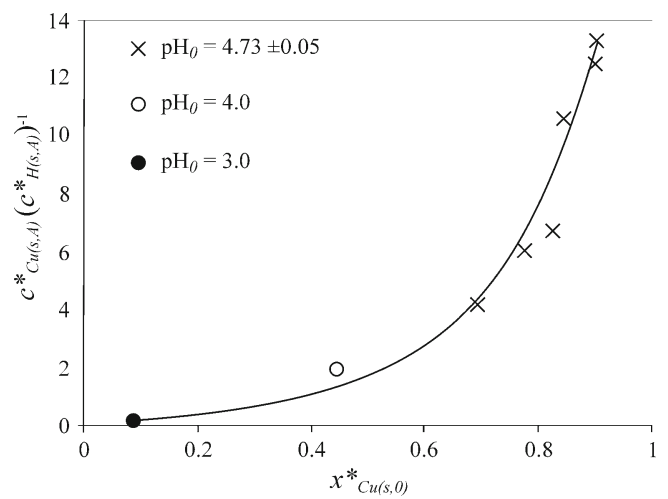

Fig. 2 Influence of the gram equivalent fraction of copper in the initial solution on the magnitude of the concentration quotient at point $\mathrm{A}$
Sorption kinetics of $\mathrm{Cu}^{2+}$ and $\mathrm{H}^{+}+\mathrm{Cu}^{2+}$ cations

Kinetics of sorption was described using the model of a pseudo-second-order chemical reaction:

$t\left(c *_{K t(a t)}\right)^{-1}=1\left(k^{\prime \prime}\left(\mathrm{c} *_{\mathrm{Kt}(\mathrm{a}, 1)}\right)^{2}\right)^{-1}+1\left(c *_{K t(a, 1)}\right)^{-1} t$

where: index $\mathrm{Kt}$ denotes the concentration of $\mathrm{Cu}^{2+}$ cations or the sum of $\mathrm{Cu}^{2+}$ and $\mathrm{H}^{+}$cations; $\mathrm{k}^{\prime \prime}$ is the rate constant for the pseudo-second reaction. The variable $\mathrm{c}^{*}{ }_{\mathrm{Kt}(\mathrm{a}, 1)}$ is the highest concentration of $\mathrm{Cu}^{2+}$ cations or the sum of $\mathrm{Cu}^{2+}$ and $\mathrm{H}^{+}$ cations absorbed in algae, which are in equilibrium with the respective cations in the solution under given thermodynamic conditions (temperature and reactant concentrations).

Further analysis of sorption kinetics included only the variation of $\mathrm{Cu}^{2+}$ concentration and the sum of $\mathrm{H}^{+}$and $\mathrm{Cu}^{2+}$ concentrations in the second phases of measurements (results located right of the A point in Fig. 1). As discussed above, the variation of concentrations observed in the first phases of measurements, left of the A point, was nonlinear due to various proportions of ions sorbed and did not match model (1). The results of our own experiments are shown in Figs $3 a$ and $b$.

The plots show that the slopes of straight lines describing the sorption of copper cations (Fig. 3a) are much less ordered than the slopes of lines corresponding to the sum of
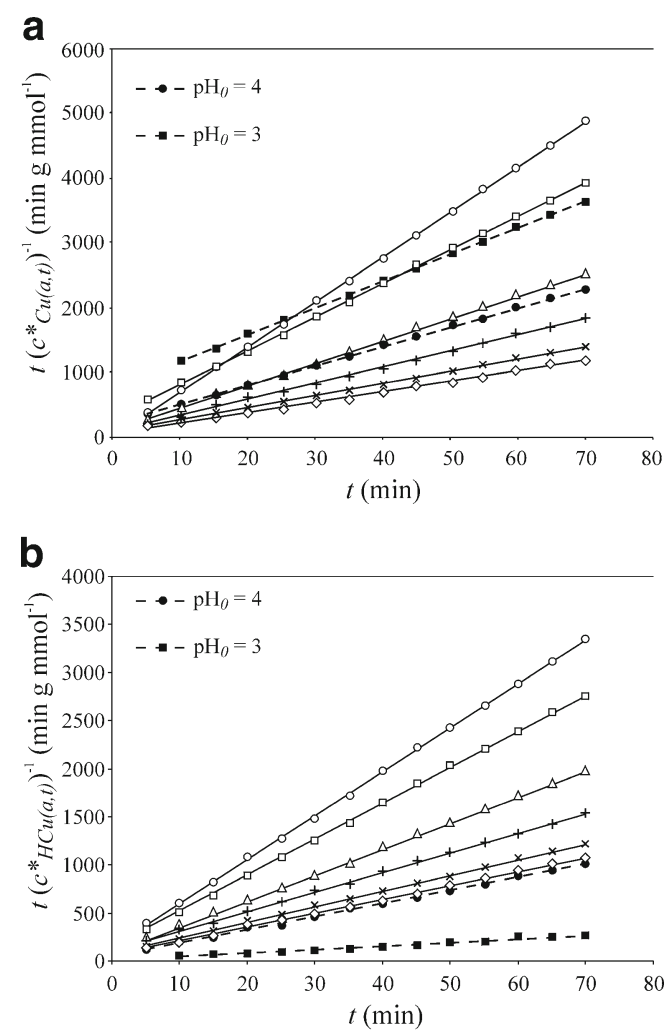

Fig. 3 Kinetics of sorption approximated with the pseudo secondorder model: a $\mathrm{Cu} 2+$ cations; b sum of $\mathrm{Cu}^{2+}$ and $\mathrm{H}^{+}$cations 
$\mathrm{H}^{+}$and $\mathrm{Cu}^{2+}$ cations (Fig. 3b) and clearly depend on the concentration of hydrogen ions.

Sorption capacity of the algae

Sorption capacity of the algae was determined using the Langmuir isotherm model:

$$
\begin{aligned}
1\left(c *_{K t(a, 1)}\right)^{-1}= & 1\left(c *_{K t(a, \max )}\right)^{-1} \\
& +1\left(c *_{K t(a, \max )} K\right)^{-1}\left(1\left(c *_{K t(s, 1)}\right)^{-1}\right)
\end{aligned}
$$

where: $c^{*}{ }_{\mathrm{Kt}(\mathrm{a}, \max )}$ is the sorption capacity of algae and $\mathrm{K}$ is the constant.

Figure 4 compares the Langmuir isotherms (Eq. 2) determined for $\mathrm{Cu}^{2+}$ cations and for the sum of $\mathrm{Cu}^{2+}$ and $\mathrm{H}^{+}$ cations.

The Langmuir isotherms also indicate the influence of hydrogen cations on the equilibrium concentrations of copper in algae and in solutions. The trend line in Fig. 3a does not cover data collected at $\mathrm{pH}_{0}$ equal to 4 and 3 .

\section{Statistical parameters of sorption kinetics and equilibria}

Table 3 lists the statistical parameters of the slopes of straight lines describing the sorption kinetics (Eq. 1) of
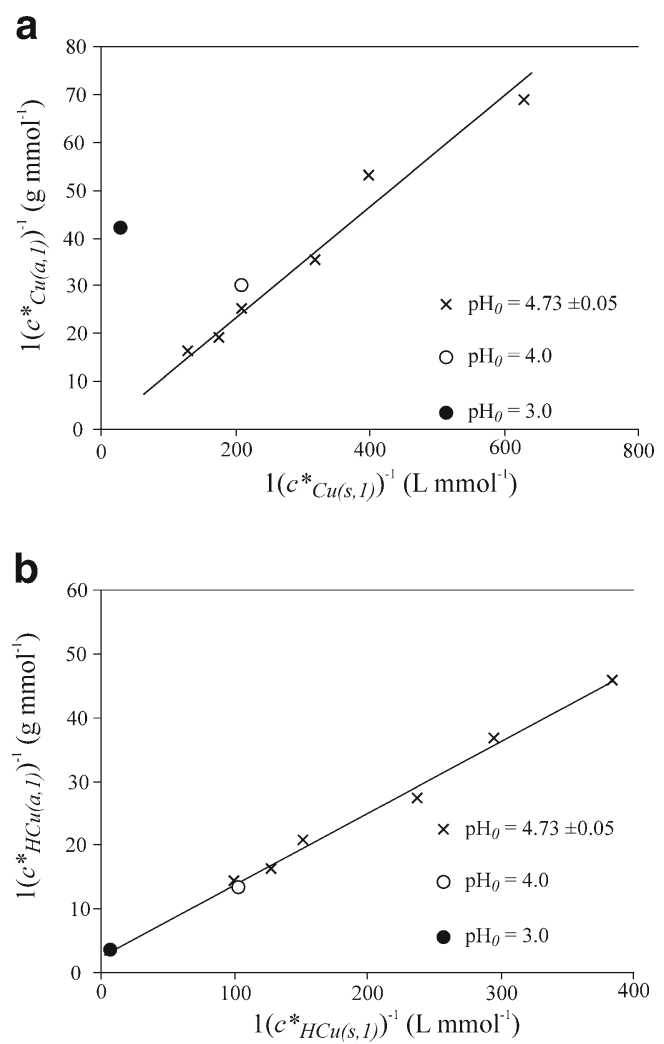

Fig. 4 Langmuir isotherms determined for: $\mathbf{a} \mathrm{Cu}^{2+}$ cations; and $\mathbf{b}$ the sum of $\mathrm{Cu}^{2+}$ and $\mathrm{H}^{+}$cations
Table 3 Statistical parameters of the slopes of straight lines $y=b \quad x+a$ describing the sorption kinetics (the pseudo-second-order reaction model,

\begin{tabular}{|c|c|c|c|c|c|c|}
\hline \multirow[t]{2}{*}{ Measurement series } & \multicolumn{3}{|l|}{$\mathrm{Cu}^{2+}$} & \multicolumn{3}{|l|}{$\mathrm{H}^{+}+\mathrm{Cu}^{2+}$} \\
\hline & $\begin{array}{l}\mathrm{b}=1 / \\
\mathrm{c}^{*} \mathrm{Cu}(\mathrm{a}, 1)\end{array}$ & $\pm \mathrm{SE}_{\mathrm{b}}$ & $\mathrm{R}^{2}$ & $\begin{array}{l}\mathrm{b}=1 / \\
\mathrm{c}^{*} \mathrm{HCu}(\mathrm{a}, 1)\end{array}$ & $\pm \mathrm{SE}_{\mathrm{b}}$ & $\mathrm{R}^{2}$ \\
\hline 1 & 69.31 & 0.70 & 0.999 & 45.94 & 0.25 & 1.000 \\
\hline 2 & 52.09 & 0.64 & 0.998 & 37.17 & 0.26 & 0.999 \\
\hline 3 & 34.51 & 0.22 & 1.000 & 27.17 & 0.14 & 1.000 \\
\hline 4 & 24.27 & 0.27 & 0.999 & 20.35 & 0.20 & 0.999 \\
\hline 5 & 18.50 & 0.17 & 0.999 & 16.01 & 0.16 & 0.999 \\
\hline 6 & 16.11 & 0.13 & 0.999 & 14.25 & 0.13 & 0.999 \\
\hline 7 & 30.01 & 0.40 & 0.998 & 13.64 & 0.13 & 0.999 \\
\hline 8 & 41.67 & 0.67 & 0.997 & 3.449 & 0.014 & 1.000 \\
\hline
\end{tabular}
Fig. 3): standard errors of slopes $b, \mathrm{SE}_{\mathrm{b}}$, and coefficients of determination $\mathrm{R}^{2}$

copper cations and of the sum of $\mathrm{H}^{+}$and $\mathrm{Cu}^{2+}$ cations. Numbering of measurement series corresponds to that in Table 2. Standard errors of the slopes and coefficients of determination indicate the results of measurements are well structured both in case of copper cations and in case of the sum of $\mathrm{H}^{+}$and $\mathrm{Cu}^{2+}$ cations. The standard error of slopes was always smaller than $2 \%$ of the value determined $(b=1$ $\left.\left(\mathrm{c}^{*} \mathrm{Kt}(\mathrm{a}, 1)\right)^{-1}\right)$.

Table 4 shows the statistical parameters of the Langmuir isotherms determined for copper cations (Fig. 4a) and for the sum of $\mathrm{H}^{+}$and $\mathrm{Cu}^{2+}$ cations (Fig. 4b). Data presented in Table 4 show that the uncertainty of determination of the sorption capacity exceeds $300 \%$ in case of copper cations and is close to $32 \%$ in case of the sum of $\mathrm{H}^{+}$and $\mathrm{Cu}^{2+}$ cations.

In order to find which parameters influenced the uncertainty of the measurement results, the component $1\left(\mathrm{c}^{*} \mathrm{Kt}(\mathrm{a}, 1)\right)^{-1}$ contained both in the kinetic model (Eq. 1) and in the equilibrium model (Eq. 2) was analysed. The values of the parameter were determined using both models and compared. For the $\mathrm{Cu}^{2+}$ and $\mathrm{H}^{+}+\mathrm{Cu}^{2+}$ experiments, the significance levels were evaluated of a hypothesis that $\left(1\left(\mathrm{c}^{*}{ }_{\mathrm{Kt}(\mathrm{a}, 1)}\right)^{-1}\right)_{\mathrm{PSO}}=\left(1\left(\mathrm{c}^{*}{ }_{\mathrm{Kt}(\mathrm{a}, 1)}\right)^{-1}\right)_{\mathrm{Ln}}$, where index PSO denoted the kinetic model while index $\mathrm{Ln}$, the equilibrium model. Table 5 shows the results of the analysis which include the coefficients of determination $\mathrm{R}^{2}$ and the significance levels $\alpha$ obtained with $\mathrm{t}$ test for the equivalent hypothesis that the free factor $\mathrm{a}=$ 0 and the slope $b=1$.

Data contained in Table 5 show that the equality (1 $\left.\left(\mathrm{c}^{*} \mathrm{Kt}(\mathrm{a}, 1)\right)^{-1}\right)_{\mathrm{PSO}}=\left(1\left(\mathrm{c}^{*} \mathrm{Kt}(\mathrm{a}, 1)\right)^{-1}\right)_{\mathrm{Ln}}$ was statistically justified both for $\mathrm{Cu}^{2+}$ and for the sum of $\mathrm{H}^{+}$and $\mathrm{Cu}^{2+}$, which in turn indicates that the mathematical models used fitted well the kinetics and equilibria of the ionic exchange process. Thus, the significant scattering of experimental points from the theoretical Langmuir isotherm in Fig. 4a as well as large standard error of the 
Table 4 Statistical parameters of the Langmuir isotherms

\begin{tabular}{lllllll}
\hline Isotherm & $\mathrm{a}$ & $\pm \mathrm{SE}_{\mathrm{a}}$ & $\mathrm{b}$ & $\pm \mathrm{SE}_{\mathrm{b}}$ & $\mathrm{R}^{2}$ & $\mathrm{c}^{*} \mathrm{Cu}(\mathrm{a}, \mathrm{max})(\mathrm{mmol} \mathrm{g})$ \\
\hline $1 / \mathrm{c}^{*}{ }_{\mathrm{Cu}(\mathrm{a}, 1)}=\mathrm{a} \cdot 1 / \mathrm{c}^{*} \mathrm{Cu}(\mathrm{s}, 1)+\mathrm{b}$, (Fig. 4a) & 0.11 & 3.34 & 1.00 & 0.0950 & 0.972 & 0.99 \\
$1 / \mathrm{c}^{*}{ }_{\mathrm{HCu}(\mathrm{a}, 1)}=\mathrm{a} \cdot 1 / \mathrm{c}^{*}{ }_{\mathrm{HCu}(\mathrm{s}, 1)}+\mathrm{b}$, (Fig. 4b) & 0.11 & 0.82 & 2.57 & 0.0039 & 0.993 & 0.39 \\
\hline
\end{tabular}

sorption capacity in Table 4 resulted probably from the competitive sorption of hydrogen cations. The largest deviation from the model was found at $\mathrm{pH}=3$ (Fig. 4a)

\section{Discussion}

The results of studies on the influence of $\mathrm{pH}$ on copper sorption by the alga $P$. palmata showed that the maximal sorption took place at $\mathrm{pH} 4.7$ (Rajfur and Kłos 2012). This is generally consistent with results obtained by other laboratories. For instance, the optimal acidity for sorption of cadmium by algae Oedogonium sp. and Ceramium virgatum Roth was pH5.0 (Gupta and Rostogi 2008b; Sari and Tuzen 2009), while that for sorption of copper by the alga Cladophora crispata (Roth) Kützing was pH4.5 (Özer et al. 2004).

The model of pseudo-second-order reaction is often used to describe the sorption kinetics in several biosorbents: algae (Senthilkumar et al. 2006); mosses (Sari and Tuzen 2009); and lichen (Uluozlu et al. 2008). It has often been compared to the model of a pseudo-first-order reaction and found to better approximate the experimental data. Impact of hydrogen cations on the kinetics of the process is rather disregarded in these research. Many authors neglected the initial phases of their experiments. For instance, they analysed data collected after first 5 min (Sari and Tuzen 2008) or even after $20 \mathrm{~min}$ (Chen et al. 2008). The results of the studies described in literature show that the parameters of sorption kinetics were dependent on concentration of the solution, which is confirmed by the results shown in the graphs in Fig. 3, but they are also related to the ratio of sorbent mass and solution volume (Gupta et al. 2006). The studies presented in this publication were carried out in the system where $1.0 \mathrm{~g} \mathrm{DM}$ of algae was dispersed in $0.4 \mathrm{~L}$ of solution.

For the alga $C$. crispata (Roth) Kützing, in which copper cations were sorbed, the biggest values of $\mathrm{k}^{\prime \prime}$ and $\mathrm{c}_{\mathrm{Kt}(\mathrm{a}, 1)}$ were observed in temperature of 298 K (Özer et al. 2004).

Table 5 Statistical indices for the hypothesis $\left(1 / \mathrm{c}^{*}{ }_{\mathrm{Kt}(\mathrm{a}, 1)}\right)_{\mathrm{PSO}}=\left(1 / \mathrm{c}^{*}{ }_{\mathrm{Kt}}\right.$ $(\mathrm{a}, 1))_{\mathrm{Ln}}(\mathrm{a}=0$ and $\mathrm{b}=1)$

\begin{tabular}{|c|c|c|c|c|c|}
\hline \multicolumn{3}{|l|}{$\mathrm{Cu}^{2+}$} & \multicolumn{3}{|c|}{$\mathrm{H}^{+}+\mathrm{Cu}^{2+}$} \\
\hline $\mathrm{R}^{2}$ & $\alpha_{a}$ & $\alpha_{\mathrm{b}}$ & $\mathrm{R}^{2}$ & $\alpha_{a}$ & $\alpha_{b}$ \\
\hline 0.980 & 0.050 & 0.705 & 0.999 & 0.051 & 0.294 \\
\hline
\end{tabular}

Our investigations were carried out in the temperature range 295-298 K.

Ion-exchange equilibrium, as in this article, was described usually using Langmuir isotherm model, and this model has often been compared to Freundlich, RedlichPeterson and Koble-Corrigan models. It assumes a monomolecular layer of sorbed molecules or ions and is formed on the sorbent surface, which is justified in case of the ionexchange processes. Also in this case, the descriptions of the sorption of heavy metal cations in algae do not include simultaneous sorption of hydrogen cations.

The sorption capacity for copper of the alga $P$. palmata, determined at comparable initial acidities of solutions (Fig. 4a), was $\mathrm{c}^{*}=0.99 \mathrm{mmol} \mathrm{g}^{-1}$ (31.5 $\left.\mathrm{mg} \mathrm{g}^{-1} \mathrm{DM}\right)$. On the other hand, the sorption capacity determined for the sum of $\mathrm{H}^{+}$ and $\mathrm{Cu}^{2+}$ at various conditions (Fig. 4b) was $\mathrm{c}^{*}=0.39 \mathrm{mmol}$ $\mathrm{g}^{-1}$ (12.4 $\left.\mathrm{mg} \mathrm{g}^{-1} \mathrm{DM}\right)$. These results, together with scattering of data in Fig. 4a, indicate that the evaluation of sorption capacity of algae is subject to large errors. Table 6 compares sorption capacities for various algae species.

Table 6 Sorption capacity for copper of various algae species ( $\mathrm{pH}$ of solutions: 4.5-5.5)

\begin{tabular}{|c|c|c|c|}
\hline Algae & $\begin{array}{l}\mathrm{c}^{*} \mathrm{Cu}(\mathrm{a}, \mathrm{max}) \\
\left(\mathrm{mmol} \mathrm{g}{ }^{-1} \text { d.m.) }\right.\end{array}$ & $\begin{array}{l}\mathrm{c}_{\mathrm{Cu}(\mathrm{a}, \max )} \\
\left(\mathrm{mg} \mathrm{g}^{-1} \text { d.m. }\right)\end{array}$ & References \\
\hline $\begin{array}{l}\text { Caulerpa lentillifera } \\
\text { J. Agardh }\end{array}$ & 0.18 & 5.72 & $\begin{array}{l}\text { (Pavasant } \\
\text { et al. 2006) }\end{array}$ \\
\hline $\begin{array}{l}\text { Codium vermilara } \\
\text { (Olivi) Delle } \\
\text { Chiaje }\end{array}$ & 0.54 & 17.2 & $\begin{array}{l}\text { (Romera } \\
\text { et al. 2007) }\end{array}$ \\
\hline $\begin{array}{l}\text { Spirogyra insignis } \\
\text { (Hassall) Kützing }\end{array}$ & 0.60 & 19.1 & \\
\hline $\begin{array}{l}\text { Sargassum fluitans } \\
\text { (Børgesen) } \\
\text { Børgesen }\end{array}$ & 0.80 & 25.4 & $\begin{array}{l}\text { (Davis et } \\
\text { al. 2003) }\end{array}$ \\
\hline $\begin{array}{l}\text { Cladophora crispata } \\
\text { (Roth) Kützing }\end{array}$ & 1.03 & 32.7 & $\begin{array}{l}\text { (Özer et } \\
\text { al. 2004) }\end{array}$ \\
\hline Ulva sp. & 1.50 & 47.7 & $\begin{array}{l}\text { (Sheng et } \\
\text { al. 2004) }\end{array}$ \\
\hline $\begin{array}{l}\text { Chaetomorpha linum } \\
\text { (O.F.Müller) } \\
\text { Kützing }\end{array}$ & 2.92 & 92.8 & $\begin{array}{l}\text { (Ajjabi and } \\
\text { Chouba } \\
\text { 2009) }\end{array}$ \\
\hline $\begin{array}{l}\text { Fucus serratus } \\
\text { Linnaeus }\end{array}$ & 3.20 & 102 & $\begin{array}{l}\text { (Ahmady- } \\
\text { Asbchin et } \\
\text { al. 2008) }\end{array}$ \\
\hline Spirogyra sp. & 4.20 & 133 & $\begin{array}{l}\text { (Gupta et } \\
\text { al. 2006) }\end{array}$ \\
\hline
\end{tabular}


Data in Table 6 also indicate large differences in the sorption capacities evaluated, which not necessarily result from different sorption properties between algae species. The studies done for the algae Spirogyra sp. showed that the evaluation uncertainty of the sorption capacity for copper reached $10 \%$, depending on the experimental procedures used (in particular - on methods of algae preparation) (Rajfur et al. 2012). Unfortunately, the authors quoted in Table 6 had not provided any error estimates.

In conclusion, the results of the research presented indicate a significant influence of hydrogen cations on the sorption of copper cations and, probably, other heavymetal cations by algae. The competitive sorption of hydrogen cations affects the kinetics and equilibria of ionic exchange of heavy metals. It increases the uncertainty of determination of such parameters as algae sorption capacity. At equal initial acidity $\left(\mathrm{pH}_{0}\right)$ of solutions, the competitive sorption of hydrogen ions decreases when initial gram equivalent fraction of copper in the solution is increased. Thus, to determine properly the sorption capacity of algae, one has to take into account the sum of sorbed cationshydrogen and copper. If the sum of cations is used in Eq. 2, the scattering of experimental points from theoretical model lines is reduced (Fig. 4).

The results show that the Langmuir isotherm and the pseudo-second-order reaction model properly describe the equilibria and kinetics of ionic exchange between algae and solutions.

Acknowledgments The Project received financial assistance from the funds of the National Science Centre granted by force of the decision no. DEC-2011/03/D/NZ9/00051.

Open Access This article is distributed under the terms of the Creative Commons Attribution License which permits any use, distribution, and reproduction in any medium, provided the original author(s) and the source are credited.

\section{References}

Ahmady-Asbchin S, Andrès Y, Gérente C, Le Cloirec P (2008) Biosorption of $\mathrm{Cu}$ (II) from aqueous solution by Fucus serratus: surface characterization and sorption mechanisms. Bioresour Technol 99:6150-6155

Ajjabi LC, Chouba L (2009) Biosorption of $\mathrm{Cu}^{2+}$ and $\mathrm{Zn}^{2+}$ from aqueous solutions by dried marine green macroalga Chaetomorpha linum. J Environ Manage 90:3485-3489

Apiratikul R, Pavasant P (2008) Batch and column studies of biosorption of heavy metals by Caulerpa lentillifera. Bioresour Technol 99:2766-2777

Balarama Krishna MV, Arunachalam J, Murali MS, Kumar S, Manchanda VK (2004) Performance of immobilized moss in the removal of ${ }^{137} \mathrm{Cs}$ and ${ }^{90} \mathrm{Sr}$ from actual low-level radioactive waste solutions. J Radioanal Nuclear Chem 261:551-557

Bhat SV, Melo JS, Chaugule BB, D'Souza SF (2008) Biosorption characteristics of uranium(VI) from aqueous medium onto Catenella repens, a red alga. J Hazard Mater 158:628-635
Bulgariu D, Bulgariu L (2012) Equilibrium and kinetics studies of heavy metal ions biosorption on green algae waste biomass. Bioresour Technol 103:489-493

Chen Z, Ma W, Han M (2008) Biosorption of nickel and copper onto treated alga (Undaria pinnatifida): application of isotherm and kinetic models. J Hazard Mater 155:327-333

Davis TA, Volesky B, Mucci A (2003) A review of the biotechnology of heavy metal biosorption by brown algae. Wat Res 37:43114330

El-Sikaily A, El Nemr A, Khaled A, Abdelwehab O (2007) Removal of toxic chromium from wastewater using green alga Ulva lactuca and its activated carbon. J Hazard Mater 148:216-228

Feng D, Aldrich C (2004) Adsorption of heavy metals by biomaterials derived from the marine alga Ecklonia maxima. Hydrometallurgy 73:1-10

Genc-Fuhrman H, Mikkelsen PS, Ledin A (2007) Simultaneous removal of $\mathrm{As}, \mathrm{Cd}, \mathrm{Cr}, \mathrm{Cu}, \mathrm{Ni}$ and $\mathrm{Zn}$ from stormwater: experimental comparison of 11 different sorbents. Water Res 41:591-602

Graham LE, Graham JM, Wilcox LW (2009) Algae. Benjamin Cummings (Pearson), San Francisco, CA

Gupta VK, Rostogi A (2008a) Biosorption of lead from aqueous solutions by green algae Spirogyra species: kinetics and equilibrium studies. J Hazard Mater 152:407-414

Gupta VK, Rostogi A (2008b) Equilibrium and kinetic modelling of cadmium(II) biosorption by nonliving algal biomass Oedogonium sp. from aqueous phase. J Hazard Mater 153:759-766

Gupta VK, Rastogi A, Saini VK, Jain N (2006) Biosorption of copper (II) from aqueous solutions by Spirogyra species. J Colloid Interface Sci 296:59-63

Gupta VK, Rastogi A, Nayak A (2010) Biosorption of nickel onto treated alga (Oedogonium hatei): application of isotherm and kinetic models. J Colloid Interface Sci 342:533-539

Hauck M, Huneck S (2007) Lichen substances affect metal adsorption in Hypogymnia physodes. J Chem Ecol 33:219-223

Herrero R, Lodeiro P, Rey-Castro C, Vilariño T, Sastre de Vicente ME (2005) Removal of inorganic mercury from aqueous solutions by biomass of the marine macroalga Cystoseira baccata. Water Res 39:3199-3210

Kłos A, Rajfur M, Wacławek M, Wacławek W (2005) Ion exchange kinetics in lichen environment. Ecol Chem Eng 12:1353-1365

Kłos A, Rajfur M, Wacławek M, Wacławek W (2007) Heavy metal sorption in the lichen cationactive layer. Bioelectrochemistry 71:60-65

Kumar D, Singh A, Gaur JP (2008) Mono-component versus binary isotherm models for $\mathrm{Cu}(\mathrm{II})$ and $\mathrm{Pb}(\mathrm{II})$ sorption from binary metal solution by the green alga Pithophora oedogonia. Bioresour Technol 99:8280-8287

Langmuir I (1918) The adsorption of gases on plane surfaces of glass, mica, and platinum. J Am Chem Soc 40:1361-1402

Lee YC, Chang SP (2011) The biosorption of heavy metals from aqueous solution by Spirogyra and Cladophora filamentous macroalgae. Bioresour Technol 102:5297-5304

Monteiro CM, Castro PML, Malcata FX (2009) Use of the microalga Scenedesmus obliquus to remove cadmium cations from aqueous solutions. World J Microbiol Biotechnol 25:1573-1578

Özer A, Özer D, Ekiz HI (2004) The equilibrium and kinetic modeling of the biosorption of copper(II) ions on Cladophora crispata. Adsorption 10:317-326

Pavasant P, Apiratikul R, Sungkhum V, Suthiparinyanont P, Wattanachira S, Marhaba TF (2006) Biosorption of $\mathrm{Cu}^{2+}, \mathrm{Cd}^{2+}$, $\mathrm{Pb}^{2+}$, and $\mathrm{Zn}^{2+}$, using dried marine green macroalga Caulerpa lentillifera. Bioresour Technol 97:2321-2329

Qaiser S, Saleemi AR, Umar M (2009) Biosorption of lead(II) and chromium(VI) on groundnut hull: equilibrium, kinetics and thermodynamics study. Electronic J Biotechnol 12:1-17 
Rajfur M, Kłos A (2012) Sorption of heavy metals in the biomass of algae Palmaria palmata. Water Sci Technol in press

Rajfur M, Kłos A, Wacławek M (2010) Sorption properties of algae Spirogyra sp. and their use for determination of heavy metal ions concentrations in surface water. Bioelectrochemistry 80:81-86

Rajfur M, Kłos A, Wacławek M (2012) Sorption of copper(II) ions in the biomass of alga Spirogyra sp. Bioelectrochemistry. doi:10.1016/j.bioelechem.2011.12.007

Romera E, Gonzàlez F, Ballester A, Blázquez ML, Muñoz JA (2007) Comparative study of biosorption of heavy metals using different types of algae. Bioresour Technol 98:3344-3353

Sari A, Tuzen M (2008) Biosorption of cadmium(II) from aqueous solution by red algae (Ceramium virgatum): equilibrium, kinetic and thermodynamic studies. J Hazard Mater 157:448-454

Sari A, Tuzen M (2009) Removal of mercury(II) from aqueous solution using moss (Drepanocladus revolvens) biomass: equilibrium, thermodynamic and kinetic studies. J Hazard Mater 171:500-507

Senthilkumar R, Vijayaraghavan K, Thilakavathi M, Iyer PVR, Velan $M$ (2006) Seaweeds for the remediation of wastewaters contaminated with zinc(II) ions. J Hazard Mater B136:791-799

Sheng PX, Ting YP, Chen JP, Hong L (2004) Sorption of lead, copper, cadmium, zinc and nickel by marine algal biomass: characterization of biosorptive capacity and investigation of mechanisms. J Colloid Interface Sci 275:131-141
Singh A, Kumar D, Gaur JP (2008) Removal of Cu(II) and Pb(II) by Pithophora oedogonia: sorption, desorption and repeated use of the biomass. J Hazard Mater 152:1011-1019

Tuzen M, Sari A, Mendil D, Soylak M (2009) Biosorptive removal of mercury(II) from aqueous solution using lichen (Xanthoparmelia conspersa) biomass: kinetic and equilibrium studies. J Hazard Mater 169:263-270

Uluozlu OD, Sari A, Tuzen M, Soylak M (2008) Biosorption of Pb(II) and $\mathrm{Cr}$ (III) from aqueous solution by lichen (Parmelina tiliaceae) biomass. Bioresour Technol 99:2972-2980

Vásquez TGP, Botero AEC, de Mesquita LMS, Torem ML (2007) Biosorptive removal of $\mathrm{Cd}$ and $\mathrm{Zn}$ from liquid streams with a Rhodococcus opacus strain. Minerals Eng 20:939-944

Vilar VJP, Botelho CMS, Boaventura RAR (2005) Influence of $\mathrm{pH}$, ionic strength and temperature on lead biosorption by Gelidium and agar extraction algal waste. Process Biochem 40:3267-3275

Wong KK, Lee CK, Low KS, Haron MJ (2003) Removal of Cu and Pb by tartaric acid modified rice husk from aqueous solutions. Chemosphere 50:23-28

Wu P, Zhou Y (2009) Simultaneous removal of coexistent heavy metals from simulated urban stormwater using four sorbents: a porous iron sorbent and its mixtures with zeolite and crystal gravel. J Hazard Mater 168:674-680

Zhang M (2011) Adsorption study of $\mathrm{Pb}(\mathrm{II}), \mathrm{Cu}(\mathrm{II})$ and $\mathrm{Zn}$ (II) from simulated acid mine drainage using dairy manure compost. Chem Eng J 172:361-368 